\title{
Podwyższenie standardu ochrony mikroprzedsiębiorcy jako odbiorcy paliw i energii na podstawie kompetencji państwa członkowskiego w prawodawstwie Unii Europejskiej
}

\begin{abstract}
Increase of the scope of the protection standard of a micro-entrepreneur as a recipient of fuel and energy pursuant to the Member State powers under the European Union legislation: The opinion presents major differences in the legal situation of clients-entrepreneurs in relation to (legally privileged) recipients being household owners and consumers. Moreover, the author presents legal arguments for an extension of the protection standard regarding privileged entrepreneurs to micro-entrepreneurs and small entrepreneurs under the European Union legislation and in compliance with the national one. The opinion contains arguments for a specific national legislation, which would provide content to the state obligation to provide assistance to the development of entrepreneurship, in particular the micro-entrepreneurs, and which would facilitate an effective use of liberties of a uniformed EU market in the trans-border dimension.
\end{abstract}

\footnotetext{
Keywords: European Union law, constitutional law, public commercial law, energy law

Słowa kluczowe: prawo unijne, prawo konstytucyjne, publiczne prawo gospodarcze, prawo energetyczne
}

\section{Wprowadzenie}

Mikroprzedsiębiorcy i mali przedsiębiorcy ${ }^{1}$ stanowią w Polsce 96\% przedsiębiorców, a spośród dwóch milionów osób fizycznych prowadzących działal-

1 W rozumieniu art. 7 ust. 1 pkt 1 i 2 ustawy - Prawo przedsiębiorców z 6 marca 2018 r. (Dz.U. poz. 646), poprzednio art. 104 i art. 105 ustawy z 2 lipca 2004 r. o swobodzie działalności gospodarczej (t.j. Dz.U. 2017, poz. 2168). 
ność gospodarczą - 1,8 mln to mikroprzedsiębiorcy². Status prawny tej grupy przedsiębiorców nie różni się od innych - średnich i większych przedsiębiorców w sferze traktowania ich jako profesjonalnych, równorzędnych uczestników obrotu prawnego z przedsiębiorstwami energetycznymi - dostawcami energii ( $\mathrm{tj}$. energii elektrycznej i energii cieplnej) oraz paliwa gazowego. Osoby fizyczne prowadzące działalność gospodarczą, z reguły w niewielkim rozmiarze lub o niskim (w ujęciu jednostkowym) progu rynkowej odczuwalności, mają trudności w zrozumieniu złożonych zagadnień prawnych i technicznych umów energetycznych i w osiągnięciu profesjonalizmu na poziomie dorównującym wyspecjalizowanemu przedsiębiorstwu energetycznemu (dalej: dostawca), o zdecydowanie większym potencjalne ekonomicznym i przygotowaniu organizacyjnym, korzystającemu z profesjonalnych doradców. Rzeczywistym problemem tej licznej grupy jednoosobowych przedsiębiorców (osób fizycznych) są: niepełna wiedza i brak znajomości procedur związanych z zawieraniem, ze szczegółowymi i skomplikowanymi postanowieniami, oraz wykonywaniem umów energetycznych, składaniem reklamacji, wstrzymaniem dostaw, naliczaniem opłat dodatkowych, wynikające z braku wiedzy technicznej oraz nieznajomości przepisów prawa i sposobów ich skutecznej realizacji. Niedostatkowi świadomości prawnej towarzyszą deficyt czasu i obawa skutków samodzielnego inicjowania środków prawnych wobec dostawcy lub w sporze z nim, z czym koreluje niedostatek środków na doradztwo techniczne i obsługę prawną. Poziom świadomości prawnej mikroprzedsiębiorców (lub też małych przedsiębiorców) nie dorównuje pozostałym przedsiębiorcom, pozostaje zbliżony do konsumentów. De lege lata prawna ochrona interesów przedsiębiorców będących osobami fizycznymi nie jest należycie zagwarantowana, mimo że acquis communautaire dostarcza pola dla krajowych rozwiązań prawnych. Prezentowane opracowanie zmierza, po pierwsze, do wyartykułowania zasadniczych różnic w sytuacji prawnej odbiorców-przedsiębiorców względem (prawnie uprzywilejowanych) odbiorców w gospodarstwie domowym, konsumentów. Po drugie, do przedstawienia przede wszystkim argumentów prawnych, co jasne, zakotwiczonych w uwarunkowaniach ekonomicznych i technicznych rynku energii i paliwa gazowego, na rzecz rozciągnięcia

2 Na podstawie danych GUS, www.stat.gov.pl [dostęp 11 lipca 2018 r.]. Wśród mikroprzedsiębiorców są osoby samozatrudnione, wykonujące działalność zawodową lub gospodarczą w warunkach domowych, $\mathrm{z}$ reguły $\mathrm{w}$ niewielkim rozmiarze, o niskim stopniu intensywności lub - w ujęciu jednostkowym - rynkowej odczuwalności, korzystające z elektronicznych form świadczenia usług lub kontaktu na odległość, pracujące w domu, przyjmujące kontrahentów czy też klientów w domu, samodzielnie wykonujące powierzone im prace lub też świadczące usługi w zorganizowanych $\mathrm{w}$ domu pracowniach, gabinetach, warsztatach, biurach, punktach usługowych (np. architekci, krawcy, lekarze, stomatolodzy, informatycy, księgowi, prawnicy, handlowcy, różnego rodzaju doradcy lub pośrednicy, drobni rzemieślnicy, tłumacze języka obcego). 
standardu ochrony odbiorców uprzywilejowanych na mikroprzedsiębiorców (co można też odnieść do małych przedsiębiorców) na podstawie prawodawstwa Unii Europejskiej i w zgodzie z prawem krajowym.

\section{Przewaga pozycji odbiorcy w gospodarstwie domowym, konsumenta nad mikroprzedsiębiorcą wobec przedsiębiorstwa energetycznego}

Ustalenie statusu odbiorcy prawnie uprzywilejowanego (względem przedsiębiorstw energetycznych - dostawców) wymaga sięgnięcia zarówno do funkcjonującego w prawie energetycznym pojęcia odbiorcy w gospodarstwie domowym, jak i do centralnego w prawie cywilnym pojęcia konsumenta, które na gruncie reżimu prawa energetycznego nie występuje. Zgodnie $\mathrm{z}$ art. 3 pkt $13 \mathrm{~b}$ ustawy z 10 kwietnia 1997 r. - Prawo energetyczne (t.j. Dz.U. 2017, poz. 220; dalej: u.p.e.): [o]dbiorca paliw gazowych, energii elektrycznej lub ciepła w gospodarstwie domowym [oznacza - przypis M.M.] - odbiorcę końcowego dokonujacego zakupu paliw gazowych, energii elektrycznej lub ciepła wyłacznie $w$ celu ich zużycia $w$ gospodarstwie domowym ${ }^{3}$. Najbardziej reprezentatywne, szczególne uprawnienia tej grupy odbiorców to: prawo do „szybszej” zmiany sprzedawcy oraz prawo do usługi powszechnej (art. $4 \mathrm{j}$ oraz art. 5 a u.p.e.). $Z$ kolei zgodnie $\mathrm{z}$ art. $22^{1}$ Kodeksu cywilnego: : [z] a konsumenta uważa się osobe fizyczna dokonujacca z przedsiębiorca czynności prawnej niezwiązanej bezpośrednio z jej działalnością gospodarcza lub zawodowa $a^{5}$. Występująca w obydwu ustawach paralelna konwencja terminologiczna może sugerować, że pojęcia odbiorcy w gospodarstwie domowym oraz konsumenta nie mają jednolitego zakresu desygnatów, które korespondują z rozbieżnymi celami obu reżimów prawnych. Konkurencyjność przedstawionych przepisów jest jednak pozorna, a założenia tego nie niweczy odmienna

3 Zob. art. 2 pkt 10 dyrektywy Parlamentu Europejskiego i Rady nr 2009/72/WE z 13 lipca 2009 r. dotyczącej wspólnych zasad rynku wewnętrznego energii elektrycznej i uchylającej dyrektywę 2003/54/WE (Dz.Urz. UE L 211 z 2009 r., s. 55); dalej: dyrektywa 2009/72/WE, oraz art. 2 pkt 25 dyrektywy Parlamentu Europejskiego i Rady 2009/73/WE z 13 lipca 2009 r. dotyczącej wspólnych zasad rynku wewnętrznego gazu ziemnego i uchylającej dyrektywę 2003/55/WE (Dz.Urz. UE L 211 z 2009 r., s. 94); dalej: dyrektywa 2009/73/WE.

4 Ustawa z 23 kwietna 1964 r. - Kodeks cywilny, t.j. Dz.U. 2018, poz. 1025, ze zm.; dalej: k.c.

5 Zmiana definicji dokonana została na podstawie art. 44 pkt 1 ustawy o prawach konsumenta, z mocą obowiązującą od 25 grudnia 2014 r. Aktualna definicja konsumenta, w porównaniu z poprzednio obowiązującą, wyraźnie wskazuje, że drugą stroną czynności prawnej ma być przedsiębiorca. Zgodnie $\mathrm{z}$ art. $22^{1} \mathrm{k}$.c. w brzmieniu obowiązującym przed dniem 25 grudnia 2014 r. konsument to: osoba fizyczna dokonujaca czynności prawnej niezwiązanej bezpośrednio z jej działalnością gospodarcza lub zawodowa. 
funkcja tych przepisów. Prawo unijne zakłada zresztą funkcjonowanie w państwach członkowskich obydwu tych pojęć odnoszących się do odbiorców energii lub paliwa gazowego ${ }^{6}$. Wykładnia funkcjonalna definicji odbiorcy w gospodarstwie domowym naprowadza na więź funkcjonalną, która identyfikuje gospodarstwo domowe jako związek człowieka lub ludzi oraz miejsca, które stanowi ośrodek, centrum życiowe, zaspokaja potrzeby socjalno-bytowe ${ }^{7}$. Trzeba jasno stwierdzić, że pojęcie odbiorcy w gospodarstwie domowym zawiera się w definicji konsumenta, dla której wystarczająca wydaje się wykładnia językowa ${ }^{8}$. W tej relacji jedynie zaznaczyć należy, że zakres pojęcia konsumenta jest szerszy, ponieważ obejmuje także przedsiębiorcę (zob. art. $43^{1}$ k.c.), który dokonuje czynności prawnej kwalifikowanej jako tzw. transakcję konsumencką, czyli właściwie funkcjonującej poza zakresem przedmiotu prowadzonej działalności gospodarczej lub zawodowej'. Dychotomiczny podział odbiorców w prawie energetycznym wyklucza mieszany charakter poboru energii lub paliwa gazowego przez odbiorcę-przedsiębiorcę w miejscu jego zamieszkania, na jednym punkcie poboru energii lub paliwa gazowego. Albo ma miejsce pobór związany z działalnością gospodarczą albo - transakcja konsumencka. Podział ten ma charakter względnie trwały - cel zużycia może podlegać zmianie, lecz nigdy zbiegowi w określonym punkcie poboru. Generalnie jednak zakresy desygnatów obydwu pojęć zawierają się w sobie i jest to ważny argument na rzecz pojmowania, na gruncie prawa krajowego, użytych w dyrektywie 2009/72/WE (elektroenergetycznej) i dyrektywie 2009/73/WE (gazowej) pojęć konsumenta i odbiorcy w gospodarstwie domowym za substytuty, czego obie te dyrektywy nie wyłączają wyraźnie stanowiąc, że pojęcia w nich unormowane są użyte wyłącznie na użytek dyrektywy ${ }^{10}$. Powyższe argumenty stanowią podstawę do przyjęcia założenia, że rozszerzenie uprawnień uprzywilejowanego odbiorcy na mikroprzedsiębiorców powinno zasadniczo polegać na implementacji reguł ochrony zarówno odbiorcy

6 Generalnie problematyka rozbieżności terminologicznej i różnic semantycznych wynika z różnic historycznych, gospodarczych, kulturowych i politycznych państw członkowskich.

7 Zob. Nowy Leksykon PWN, red. A. Dyczkowski, Warszawa 1998, s. 568; por. Uniwersalny słownik języka polskiego, t. 1, A-G, red. S. Dubisz, Warszawa 2003, s. 1054, a także Inny słownik języka polskiego PWN, red. M. Bańko, Warszawa 2000, s. 469, oraz Słownik 100 tysięcy potrzebnych słów, red. J. Bralczyk, Warszawa 2005, s. 212.

8 Zob. P. Mikłaszewicz, Komentarz do art. $22^{1}$ k.c. [w:] Kodeks cywilny. Komentarz, t. 1, red. K. Osajda, Warszawa 2017, s. 166-173, oraz M. Pazdan, Komentarz do art. $22^{1}$ k.c. [w:] Kodeks cywilny. Komentarz, t. 1, red. K. Pietrzykowski, Warszawa 2015, s. $103-106$.

9 Zob. M. Bednarek, Wzorce umów [w:] System prawa prywatnego, t. 5, Prawo zobowiązań - część ogólna, A. Olejniczak, Warszawa 2006, s. 577-578. Por. J.P. Naworski, Przedsiębiorca versus konsument, „Studia Prawa Prywatnego” 2018, nr 1, s. 33-50.

10 Zob. art. 2 in fine dyrektywy 2009/72/WE i art. 2 in fine dyrektywy 2009/73/WE. 
w gospodarstwie domowym, jak i konsumenta. Rozważyć należy poszczególne przejawy tej ochrony, czy istotnie pozostają adekwatne do sytuacji mikroprzedsiębiorcy działającego w warunkach domowych.

Umowy zawierane między dostawcą energii lub paliwa gazowego a odbiorcą $\mathrm{w}$ gospodarstwie domowym zawierane są zasadniczo przez przystąpienie (tzw. umowy adhezyjne). Kontrakt tego rodzaju charakteryzuje się brakiem rokowań co do treści umowy i formalnie ujętym konsensem ${ }^{11}$. Przewaga ekonomiczna i organizacyjna dostawcy z jednej strony, a z drugiej strony brak należytego rozeznania na rynku oraz brak specjalistycznej, prawniczej wiedzy odbiorców w gospodarstwie domowym w praktyce zniechęcają tych ostatnich do podejmowania negocjacji z przedsiębiorstwem energetycznym. Spostrzeżenie to w całości odnieść należy do mikroprzedsiębiorców, mimo tego że w tym zakresie nie korzystają w Polsce w żadnym stopniu z podwyższonego standardu ochrony (preferencji) strony „słabszej” w obrocie prawnym. Tylko pozornie równość jest zachowana pomiędzy zatwierdzanymi przez Prezesa Urzędu Regulacji Energetyki (URE) taryfami (cen i stawek opłat), a w odniesieniu do mikroprzedsiębiorców - przyjmowanymi przez (organy) dostawców cenników (jako wzorców umów), w odniesieniu do braku konieczności ich doręczenia odbiorcom przed dniem ich wejścia $w \dot{z} y c i{ }^{12}$. Po pierwsze, mechanizm poddania prewencyjnej kontroli Prezesa URE postanowień umowy w zakresie cen i stawek opłat, czyli udział w kształtowaniu taryfy wyspecjalizowanego organu państwowego (Prezesa URE), w którego kompetencji leży zapewnienie optymalnej ochrony interesów odbiorców (art. 23 ust. 1 in fine i ust. 2 pkt 2 u.p.e.) zawężony jest tylko do odbiorców w gospodarstwie domowym, wobec zwolnienia dostawców z obowiązku przedkładania do zatwierdzenia taryf dla przedsiębiorców (uwolnienia obrotu dwustronnie handlowego). Po drugie, konsekwencją otwartej konkurencji cenowej dostawców wobec przedsiębiorców jest rekompensowanie jej kosztów po-

11 Tak E. Łętowska, Prawo umów konsumenckich, Warszawa 2002, s. 296; zob. eadem, Europejskie prawo umów konsumenckich, Warszawa 2004, s. 256, oraz Z. Radwański, Teoria umów, Warszawa 1977, s. 91-93.

12 Zob. art. 47 u.p.e. i art. $384 \$ 2$ zdanie 1 k.c., a także uchwałę SN (7) z 15 lutego 2007 r., sygn. akt III CZP 111/06, w której uzasadnieniu SN stwierdził, że: $w$ kwestii będącej przedmiotem zagadnienia prawnego, tj. terminu obowiazywania nowej taryfy dla energii, pierwszeństwo znajduje art. 47 ust. 4 ustawy - Prawo energetyczne przed art. $384^{1}$ k.c. określającym podstawowy model zmiany wzorca umów w stosunku o charakterze ciągtym. Artykuł $384^{1}$ k.c. nie ma zastosowania również $w$ zakresie, w którym - odwołując się do art. 384 k.c. - określa sposób prawidłowego zakomunikowania drugiej stronie treści nowego wzorca (przez doręczenie), zgodnie bowiem $z$ art. 5 ust. 5 ustawy Prawo energetyczne nie ma obowiązku doręczania adherentowi zatwierdzonych taryf. Zatwierdzoną przez Prezesa URE taryfę dostawca wprowadza do stosowania wobec odbiorców nie wcześniej niż po upływie 14 dni i nie później niż do 45 dnia od daty jej opublikowania w Biuletynie URE. 
dejmowaniem wobec mikroprzedsiębiorców zachowań spełniających przesłanki nieuczciwych praktyk rynkowych ${ }^{13}$ czy też narzucaniu (z reguły w sposób zawoalowany) postanowień mających cechy klauzul abuzywnych (o czym w dalszej części artykułu). Rozproszenie oraz niski potencjał organizacyjny mikroprzedsiębiorców stanowią strukturalnie przeszkodę do wypracowania zorganizowanych form obrony interesów względem dostawców.

Unijna regulacja tzw. prawa wyboru sprzedawcy ${ }^{14}$, transponowana do prawodawstwa krajowego, uprawnia odbiorcę w gospodarstwie domowym do wypowiedzenia (każdej) umowy, na której podstawie dostarczana jest energia elektryczna lub paliwo gazowe, $\mathrm{z}$ ostatnim dniem miesiąca następującego po miesiącu, w którym oświadczenie tego odbiorcy dotarło do dostawcy, chyba że odbiorca wskaże termin późniejszy (zob. bezwzględnie obowiązujący art. 4j ust. 4 u.p.e.). Jeżeli umowa zawarta została na czas nieoznaczony, to odbiorca nie jest zobowiązany do poniesienia jakichkolwiek kosztów (np. kary umownej), z zastrzeżeniem (co oczywiste) obowiązku pokrycia należności za pobraną energię lub świadczone usługi (art. 4 j ust. 3 u.p.e.), przy jednoczesnym obowiązku dotychczasowego sprzedawcy rozliczenia się z odbiorcą w ustawowym terminie (art. 4 j ust. 7 u.p.e.). Regulacja sprzyja zwiększeniu jakości obsługi i większej dbałości dostawców o utrzymanie klientów w segmencie gospodarstw domowych.

Wstrzymanie dostaw energii lub paliwa gazowego do odbiorcy w gospodarstwie domowym, który zwleka z zapłatą za świadczone usługi (art. 6b ust. 1 pkt 2 i ust. 2 u.p.e.), musi być poprzedzone wezwaniem do uregulowania zaległych i bieżących należności w okresie 14 dni od dnia otrzymania tego wezwania (art. 6 b ust. 3 u.p.e.). Unormowanie chroni ciągłość dostaw do odbiorcy, gwarantuje mu dodatkową informację o zadłużeniu.

Odbiorcy w gospodarstwie domowym, któremu grozi wstrzymanie dostarczania energii elektrycznej albo któremu wstrzymano dopływ energii elektrycznej realizowanej na podstawie umowy z dostawcą, przysługuje prawo złożenia reklamacji, w tym ostatnim przypadku - na wstrzymanie dostarczania energii (art. 6c ust. 1 oraz art. 6d ust. 1 u.p.e.). W takim wypadku sprzedawca nie może wstrzymać dostaw energii elektrycznej albo zobowiązany jest wznowić dostarczanie energii w terminie 3 dni od dnia otrzymania reklamacji i kontynuować dostawę do czasu jej rozpatrzenia (też art. $6 c$ ust. 2 u.p.e.). W razie negatywnego rozpatrzenia reklamacji odbiorca w gospodarstwie domowym może skorzystać $\mathrm{z}$ drogi prawnej - w postaci wniosku o rozpatrzenie sporu do koordynatora przy

13 Sprzecznie z dobrymi obyczajami wywierając wpływ na sferę motywacyjną i w sposób zniekształcający postrzeganie rzeczywistości przed zawarciem umowy, w trakcie jej zawierania lub po jej zawarciu - por. art. 4 i n. ustawy z 23 sierpnia 2007 r. o przeciwdziałaniu nieuczciwym praktykom rynkowym (t.j. Dz.U. 2017, poz. 2070), która normuje ochronę (tylko) konsumentów.

14 Zob. art. 3 ust. 3 i 4 dyrektywy 2009/72/WE oraz art. 3 ust. 3 dyrektywy 2009/73/WE. 
Prezesie URE, a następnie odwołania do sądu - i w dalszym toku postępowania obezwładnić prawo dostawcy do wstrzymania dostaw albo zaktualizować obowiązek dostawcy kontynuowania dostaw do czasu prawomocnego zakończenia sprawy (art. 6c ust. 3 oraz art. 6d ust. 2 u.p.e.). Dodatkową preferencją dla odbiorcy w gospodarstwie domowym jest fikcja prawna uznania reklamacji przez dostawcę (za uzasadnioną), jeżeli w terminie 14 dni od dnia jej złożenia nie zostanie rozpatrzona (art. 6c ust. u.p.e.).

Status odbiorcy jako konsumenta poszerza zakres środków ochrony kontraktowej strony słabszej. Środki te unormowane są w Kodeksie cywilnym, np. w zakresie skutku nieprzejrzystości (nietransparentności) wzorca tłumaczonego in dubio contra proferentem (czyli na korzyść konsumenta) ${ }^{15}$ czy braku związania tzw. niedozwolonymi postanowieniami umownymi (klauzulami abuzywnymi) ${ }^{16}$ - na podstawie orzeczeń, których rozszerzona prawomocność oznacza skuteczność wobec wszystkich konsumentów, którzy zawarli umowę $\mathrm{z}$ określonym w orzeczeniu dostawcą na podstawie wzorca wskazanego w decyzji Prezesa UOKiK lub w orzeczeniu sądu ${ }^{17}$. Wzmożoną ochronę konsumentów zapewnia obowiązek Prezesa UOKiK wszczęcia z urzędu postępowania w sprawach praktyk naruszających zbiorowe interesy konsumentów oraz postępowania

15 Artykuł 385 k.c. stanowi: $\$ 1$. W razie sprzeczności treści umowy z wzorcem umowy strony sa związane umową. $\$ 2$. Wzorzec umowy powinien być sformułowany jednoznacznie i w sposób zrozumiały. Postanowienia niejednoznaczne tłumaczy się na korzyść konsumenta. Zasady wyrażonej $w$ zdaniu poprzedzajacym nie stosuje się $w$ postępowaniu w sprawach o uznanie postanowień wzorca umowy za niedozwolone. Zob. M. Bednarek, Wzorce umów, op. cit., s. 615 i 649-651; por. Z. Radwański [w:] System prawa prywatnego, t. 2, Prawo cywilne - część ogólna, red. Z. Radwański, Warszawa 2008, s. 87-88 i 93; por. także E. Łętowska, Europejskie prawo umów konsumenckich, op. cit., s. 263-264 i 275-277, oraz eadem, Prawo umów konsumenckich, op. cit., s. 322 i 40, jak również eadem, Ochrona niektórych praw konsumentów. Komentarz, Warszawa 2001, s. 95.

16 Art. $385^{1} \$ 1-3$ k.c. Zob. E. Zelek, Niedozwolone klauzule umowne w umowach sprzedaży energii elektrycznej, „Energetyka” 2012, nr 5, www.cire.pl [dostęp 11 lipca 2018 r.].

17 Zob. art. $479^{42} \$ 1$ Kodeksu postępowania cywilnego i art. $479^{43}$ Kodeksu postępowania cywilnego w brzmieniu obowiązującym do dnia 4 sierpnia 2015 r., oraz art. $479^{45}$ $\$ 2$ Kodeksu postępowania cywilnego obowiązującym do dnia 17 kwietnia 2026 r. na podstawie ustawy z 5 sierpnia 2015 r. o zmianie ustawy o ochronie konkurencji i konsumentów oraz niektórych innych ustaw, Dz.U. poz. 1634. Na podstawie art. 8 tej ustawy, rejestr klauzul niedozwolonych przestanie obowiązywać od dnia 18 kwietnia 2026 r. - funkcje rejestru wypełnią (już obecnie) publikowane decyzje Prezesa UOKiK (oraz wyroki sądów) w sprawach o uznanie postanowień wzorca umowy za niedozwolone lub w sprawach praktyk naruszających zbiorowe interesy konsumentów. Zob. także art. 23b-23d ustawy z 16 lutego 2007 r. o ochronie konkurencji i konsumentów, t.j. Dz.U. 2017, poz. 229. 
w sprawach o uznanie postanowień wzorca umowy za niedozwolone, a także zagrożenie kary pieniężną nakładaną na przedsiębiorstwo energetyczne w wysokości do 10000 euro za każdy dzień opóźnienia w wykonaniu ww. decyzji Prezesa UOKiK lub wydanych w tych sprawach wyroków sądowych ${ }^{18}$.

Nie do przecenienia pozostaje dorobek orzeczniczy sądów i decyzji Prezesa UOKiK. Najliczniejsza grupa zakwestionowanych (sprzecznych z dobrymi obyczajami i naruszających interes konsumenta) postanowień umownych, którymi posługiwali się dostawcy w umowach $\mathrm{z}$ konsumentami, i które znalazły się w rejestrze klauzul niedozwolonych, dotyczyła zagadnień związanych z niewykonaniem lub nienależytym wykonaniem zobowiązania. Wśród najbardziej jaskrawych naruszeń prawa trzeba wyróżnić zastrzeżenie przez dostawcę (na swoją rzecz) prawa do wypowiedzenia umowy w przypadku uznania, że konsument nie wykonał lub nienależycie wykonał umowę ${ }^{19}$, czy klauzulę przewidującą, na wypadek sporu z konsumentem, właściwość miejscową sądu powszechnego siedziby dostawcy ${ }^{20}$. Konieczność prowadzenia sprawy sądowej w znacznym oddaleniu od miejsca zamieszkania stanowi dla każdego odbiorcy, a nie tylko konsumenta, poważną niedogodność, zniechęcającą do dochodzenia swoich uzasadnionych roszczeń. Za niedozwoloną uznana została klauzula umowna ustalająca płatność należności za dostarczoną energię w terminie określonym w treści faktury, a nie w umowie, liczonym od dnia wystawienia faktury, przez co konsument, uwzględniając późniejszą datę jej otrzymania, mógł nie mieć wystarczającego, rozsądnego terminu na zapłatę ${ }^{21}$.

Środki ochrony konsumenta, jako strony słabszej umowy, regulują także przepisy szczególne, np. ustawa z 30 maja 2014 r. o prawach konsumenta (t.j. Dz.U. 2017, poz. 683), m.in. art. 36 pkt 1a i $1 b^{22}$ w zakresie prawa konsumenta

18 Art. 49 ust. 1 ustawy o ochronie konkurencji i konsumentów. Zob. też art. 99a-107 tej ustawy.

19 Zob. wyrok Sądu Okręgowego w Warszawie - Sądu Ochrony Konkurencji i Konsumentów (SOKiK) z 31 lipca 2012 r., sygn. akt XVII Amc 5029/11, oraz postanowienie umowy wpisane do rejestru klauzul niedozwolonych pod numerem 5228, www. uokik.gov.pl/rejestr [dostęp 11 lipca 2018 r.].

20 Zob. wyrok SOKiK z 18 października 2004 r., sygn. akt XVII Amc 101/03, postanowienie umowy wpisane do rejestru klauzul niedozwolonych pod numerem 353; zob. także wyrok SOKiK z 14 marca 2005 r., sygn. akt XVII Amc 6/04, oraz postanowienie umowy wpisane do rejestru klauzul niedozwolonych pod nr 494, wszystkie na www. uokik.gov.pl/rejestr [dostęp 11 lipca 2018 r.].

${ }_{21}$ Zob. wyrok SOKiK z 14 marca 2005 r., sygn. akt XVII Amc 6/04, postanowienia umowy wpisane do rejestru klauzul niedozwolonych pod numerami 495 i 496, www. uokik.gov.pl/rejestr [dostęp 11 lipca 2018 r.].

22 Zob. także Ustawa o prawach konsumenta. Komentarz, M. Namysłowska, D. Lubasz, Warszawa 2015, oraz Ustawa o prawach konsumenta, red. D. Karczewska, M. Namysłowska, T. Skoczny, Warszawa 2015. 
do wypowiedzenia umowy zawartej poza lokalem przedsiębiorstwa sprzedawcy (lub jego przedstawiciela, np. agenta) albo zawartej na odległość, a także ustawa o przeciwdziałaniu nieuczciwym praktykom rynkowym.

Dodatkowo ustawa o prawach konsumenta oraz ustawa - Prawo energetyczne względem odbiorców w gospodarstwie domowym nakładają na dostawców obowiązek umieszczenia w umowach informacji (lub przekazania na nośniku) poszerzających zakres wiedzy odbiorcy w sprawie nawiązanego $\mathrm{z}$ dostawcą stosunku prawnego (np. o cenie, okresach rozliczeniowych, taryfie i miejscu jej udostępnienia, możliwości uzyskania pomocy w przypadku wystąpienia awarii, sposobie wnoszenia skarg, reklamacji i rozstrzygania sporów, odpowiedzialności za jakość świadczenia, sposobie i terminie wypowiedzenia umowy, danych adresowych dostawcy ${ }^{23}$. Niedochowanie wymogów udzielenia informacji lub niewydanie dokumentów potwierdzających zawarcie umowy jest zagrożone grzywną z tytułu wykroczenia, a dodatkowo niedostosowanie wymogów działalności dostawcy do przepisów ustawy o prawach konsumenta może być uznane za nieuczciwą praktykę rynkową zagrożoną karą pieniężną ${ }^{24}$.

Powyżej zaprezentowane przejawy ochrony prawnej odbiorcy-konsumenta wydają się pozostawać zbieżne, co do przyczyn, które ją uzasadniają, z sytuacją mikroprzedsiębiorcy działającego w warunkach domowych. Do ustalenia pozostają zatem właściwości prawa unijnego w relacji do kompetencji prawodawczej państwa członkowskiego oraz podstawy i granice możliwej normatywnie preferencji mikroprzedsiębiorców.

\section{Właściwości prawa unijnego wobec kompetencji prawodawczej państwa członkowskiego}

Rozważanie przewidzianej w dyrektywach elektroenergetycznej i gazowej kompetencji państwa członkowskiego do rozciągnięcia przewidzianego $\mathrm{w}$ prawie unijnym standardu ochrony odbiorcy $\mathrm{w}$ gospodarstwie domowym i konsumenta na krajowych mikroprzedsiębiorców musi przebiegać na płaszczyźnie (i wymaga przestrzegania treści zasad) oddziaływania reżimu prawa unijnego na krajowy porządek prawny, za czym przemawiają następujące argumenty. Po pierwsze, w hierarchii źródeł prawa acquis communautaire jest usytuowana

${ }^{23}$ Zob. art. 5 ust. 4 b u.p.e oraz art. 8 i art. 12 ustawy o prawach konsumenta. Zob. także T. Długosz, Ochrona konsumenta $w$ sektorze energetycznym - zagadnienia wybrane [w:] Ochrona konsumentów i jej współczesne wyzwania, red. M. Ganczar, E. Sługocka-Krupa, Lublin 2014, s. 196-206.

$24 \mathrm{Z}$ tytułu wykroczenia grzywną do 5 tys. złotych, a z tytułu nieuczciwej praktyki rynkowej - karą pieniężną wymierzoną przez Prezesa UOKiK, w wysokości do 10\% przychodu przedsiębiorstwa w poprzedzającym roku obrotowym - źródło wprowadzonych zmian: art. $45 \mathrm{i}$ art. 49 ustawy o prawach konsumenta. 
ponad krajowym porządkiem prawnym państwa członkowskiego, czego przejawem jest supremacja (pierwszeństwo, prymat zastosowania), bezpośrednia skuteczność prawa unijnego oraz obowiązek prounijnej wykładni prawa krajowego (tzw. pośredniego stosowania prawa unijnego). Po drugie, unormowanie działalności sektora energii w prawie Unii Europejskiej ograniczyło swobodę legislacyjną państw członkowskich w tym zakresie, która dodatkowo może zostać jeszcze uszczuplona przez organy Unii na podstawie zasady subsydiarności. Choć zaznaczyć trzeba, że w analizowanym zakresie wypracowanie wspólnych, szczegółowych rozwiązań dla państw członkowskich nie byłoby proste. Powyższe właściwości prawodawstwa unijnego wyznaczają przestrzeń do ustalenia praw i wolności gospodarczych, a jednocześnie delimitują w tym zakresie swobodę prawodawstwa krajowego ${ }^{25}$.

Rozważany w prawie krajowym standard ochrony mikroprzedsiębiorcy, zgodnie $\mathrm{z}$ wypracowaną $\mathrm{w}$ wyniku orzecznictwa Trybunału Sprawiedliwości Unii Europejskiej (TSUE; poprzednio - Europejski Trybunał Sprawiedliwości, ETS) zasadą supremacji prawa unijnego, nie może przeważać nad prawem wywodzącym się z TUE ${ }^{26}$ oraz TFUE ${ }^{27}$. Uzasadnieniem koncepcji jest samoistność unijnego porządku prawnego i konieczność jednolitego stosowania we wszystkich państwach członkowskich w celu uniknięcia dyskryminacji ${ }^{28}$. Według TSUE w sytuacji, gdy sąd krajowy stwierdzi sprzeczność normy prawa krajowego $\mathrm{z}$ unijnym systemem prawnym (prawem ponadnarodowym), to powinien odmówić zastosowania takiej normy (zawiesić tymczasowo jej wykonanie wobec

25 Mechanizm oddziaływania porządku prawnego UE na prawo krajowe (tzw. europeizacja prawa), którego konsekwencją jest przekształcanie tego ostatniego przez europejską myśl prawniczą i orzecznictwo ETS, pociąga za sobą dwa następstwa. Pierwsze, negatywne, polega na zakazie wydawania aktów normatywnych oraz indywidualnych aktów administracyjnych niezgodnych z prawodawstwem unijnym. Drugie, pozytywne, polega na obowiązku państwa członkowskiego harmonizacji prawa krajowego z prawodawstwem Unii w celu zapewnienia realizacji celów traktatowych, w tym funkcjonowania wspólnego rynku.

26 Traktat o Unii Europejskiej, wersja skonsolidowana, Dz.Urz. UE C 326 z 2012 r., s. 13; dalej: TUE.

27 Traktat o funkcjonowaniu Unii Europejskiej, wersja skonsolidowana, Dz.Urz. UE C 326 z 2012 r. s. 47; dalej: TFUE.

28 Zob. wyrok ETS z 15 lipca 1964 r. w sprawie 6/64, Flaminio Costa v. E.N.E.L. (wniosek o wydanie orzeczenia w trybie prejudycjalnym Giudice conciliatore di Milano - Włochy), który potwierdził zasadę pierwszeństwa prawa unijnego względem krajowych porządków prawnych. Zgodnie z wyrokiem państwa członkowskie przeniosły na Unię (wówczas na wspólnoty) w sposób trwały i niepodważalny część swoich praw suwerennych, w tym kompetencji prawotwórczych do tworzenia odrębnego systemu prawa. Prawo wywodzące się z traktatów powołujących wspólnoty wiąże państwa członkowskie i ich obywateli oraz nie może być sprzeczne z tym systemem prawa. 
podmiotów zobowiązanych) i orzec na podstawie prawa unijnego, ponieważ tylko w ten sposób może zapewnić efektywność prawa unijnego ${ }^{29}$.

Zasada bezpośredniej skuteczność (stosowalności) prawa unijnego, polegająca na takiej właściwości niektórych jego norm, że mogą stanowić samodzielną podstawę realizacji, w tym dochodzenia przed sądem krajowym (i organami publicznymi) praw obywateli i jednostek organizacyjnych, bez pośrednictwa prawodawstwa krajowego ${ }^{30}$, pozostaje silnie uwarunkowana dobrowolnością państwa członkowskiego rozszerzenia standardu ochrony na mikroprzedsiębiorców oraz jakością przyjętej krajowej regulacji (ustawy). Generalnie podstawą tego skutku jest to, że prawo unijne wchodzi w życie jako integralna część składowa systemów prawnych państw członkowskich, a cały dorobek prawny (acquis communautaire) obowiązuje bezpośrednio $\mathrm{z}$ racji członkostwa państwa $\mathrm{w} \mathrm{UE}^{31}$.

Z orzecznictwa TSUE wynikają pewne kryteria, które akt prawa unijnego musi spełnić w celu bezpośredniej skuteczności. Otóż prawa i obowiązki muszą być wystarczająco jasne i precyzyjne (jednoznaczne) tak, aby zrekonstruować adresata uprawnienia, treść prawa i podmiot zobowiązany. Muszą być także merytorycznie bezwarunkowe, a nałożone wprost obowiązki nie mogą pozostawiać państwom członkowskim swobody decyzyjnej w tej kwestii ${ }^{32}$. Dyrektywy elektroenergetyczna i gazowa wiążą każde państwo członkowskie, do którego zostały skierowane, w odniesieniu do rezultatu, który ma być osiągnięty, oraz pozostawiają organom krajowym swobodę wyboru formy i środków implementacji do prawodawstwa krajowego (art. 288 zdanie 3 TFUE). Prawidłowa implementacja dyrektywy uprawnia jednostki do powoływania się w realizacji swoich

29 Zastosowany przez sąd krajowy środek miałby charakter proceduralny, chronić przed zastosowaniem obowiązku krajowego kolidującego z normą prawa unijnego. Nie miałby tworzyć normy prawa materialnego - por. wyrok ETS z 9 marca $1978 \mathrm{r}$. w sprawie 106/77, Amministrazione delle Finanze dello Stato v. Simmenthal, ECR 1978, s. 629. Por. także wyrok ETS z 21 lutego 1991 r. w sprawach połączonych C-143/88 i C-92/89, Zuckerfabrik Süderdithmarschen AG v. Hauptzollamt Itzehoe oraz Zuckerfabrik Soest GmbH v. Hauptzollamt Paderborn, ECR 1991, s. I-415, oraz wyrok ETS z 25 lutego 1991 r. w sprawie C-213/89, The Queen v. Secretary of State for Transport, ex parte Factortame Ltd and others, ECR 1990, s. I-2433, jak też wyrok ETS z 11 stycznia 2000 r. w sprawie C-285/98, Tanja Kreil v. Bundesrepublik Deutschland, ECR 2000, s. I-69. Zob. A. Kalisz, Wykładnia i stosowanie prawa wspólnotowego, Warszawa 2007, s. 100-107; zob. także S. Biernat, Zasada efektywności prawa wspólnotowego w orzecznictwie Europejskiego Trybunału Sprawiedliwości [w:] Studia z prawa Unii Europejskiej, red. S. Biernat, Kraków 2000, s. 28-32 i s. 71.

30 Por. wyrok ETS z 5 lutego 1963 r. w sprawie 26/62, NV Algemene Transport-en Expeditie Onderneming van Gend \& Loos v. Nederlandse administratie der belastingen, ECR 1963, s. 1. Zob. S. Biernat, Zasada efektywności prawa wspólnotowego, op. cit., s. 32; zob. także M. Ahlt, Prawo europejskie, Warszawa 1998, s. 25-29.

31 Zob. A. Kalisz, Wykładnia i stosowanie prawa wspólnotowego, op. cit., s. 38-39.

32 Ibidem, s. 41-45; zob. także M. Ahlt, Prawo europejskie, op. cit., s. 27-29. 
praw bezpośrednio na prawodawstwo krajowe. Natomiast w razie nienależytej implementacji (z czym wiązać trzeba ryzyko niedostatecznej jakości prawa krajowego, np. określenie w sposób niejasny kręgu podmiotów uprawnionych lub katalogu praw, oraz konieczność prounijnej wykładni prawa krajowego), przy jednoczesnym spełnieniu kryteriów bezpośredniej stosowalności, jednostka może powołać się bezpośrednio na przepisy dyrektywy wobec państwa (i jego organów, czyli na płaszczyźnie pionowej) w celu efektywnej realizacji roszczeń wynikających z prawa unijnego. W takim też wypadku prawo to nie przysługuje jednak państwu wobec jednostki ani też jednostkom w stosunkach poziomych (równorzędnych) ${ }^{33}$. W tej ostatniej relacji trzeba podkreślić, że prawo odbiorcy energii lub paliwa gazowego domagania się zaspokojenia roszczeń przez dostawcę ma charakter publicznoprawny, a kierowane jest do organów państwowych (Prezesa URE, sądu) z żądaniem jego zrealizowania ${ }^{34}$. Zgodnie ze stanowiskiem TSUE $\mathrm{w}$ razie sprzeczności prawa krajowego z treścią dyrektywy dla realizacji praw jednostki obowiązek bezpośredniego jej zastosowania rozciąga się - obok sądów krajowych - także na krajowe organy administracji (np. Prezesa URE) ${ }^{35}$.

W świetle zaprezentowanych wyżej wywodów na organach państw członkowskich spoczywa obowiązek prounijnej wykładni przepisów prawa (tzw. pośredniego, efektywnego stosowania prawa). Osiągnięciu pełnej efektywności tego prawa służy, szczególnie w sferze realizacji roszczeń (ochrony praw podmiotowych), powinność nadania przez sąd krajowy normie prawnej takiej treści, która pozwoli na optymalne osiągnięcie wyznaczonych przez prawo unijne celów, czyli taka rekonstrukcja tejże normy, która jest maksymalnie korzystna z punktu widzenia praw jednostki ${ }^{36}$. Z powyższym koresponduje stanowisko Trybunału Konstytucyjnego, który w uzasadnieniu wyroku z 17 lipca 2007 r., sygn. akt P 16/06, stwierdził, że: interpretacja granic swobody gospodarczej i swobody umów (także dokonywana przez TK) powinna uwzględniać kierunek wykładni, który jest najbardziej zgodny z koncepcja rozwiązań obowiązujących $w$ prawie wspólnoto-

33 Por. wyroki ETS z: 4 grudnia 1974 r. w sprawie 41/74, Yvonne van Duyn v. Home Office, ECR 1974, s. 1337; 14 lipca 1994 r. w sprawie C-91/92, Paola Faccini Dori v. Recreb Srl, ECR 1994, s. I-3325; 19 stycznia 1982 r. w sprawie 8/81, Ursula Becker v. Finanzamt Münster-Innenstadt, ECR 1982, s. 53. Zob. A. Kalisz, Wykładnia i stosowanie prawa wspólnotowego, op. cit., s. 78-80, i powołane tam orzecznictwo; zob. także S. Biernat, Zasada efektywności prawa wspólnotowego, op. cit., s. 37-40, i powołane tam orzecznictwo. Szerzej M. Marszałek, Prawo do energii, „Państwo i Prawo” 2017, z. 11, s. 70-84.

35 Zob. wyrok ETS z 22 czerwca 1989 r. w sprawie C-103/88, Fratelli Costanzo SpA v. Comune di Milano, ECR 1989, s. 1839.

36 Por. wyrok ETS z 14 lipca 1994 r. w sprawie C-91/92, Paola Faccini Dori v. Recreb Srl. Zob. A. Kalisz, Wykładnia i stosowanie prawa wspólnotowego, op. cit., s. 81-82 i 199-208, oraz powołane tam orzecznictwo; zob. także M. Adamczak-Retecka, Efektywność jako zasada prawa wspólnotowego [w:] Zasady ogólne prawa wspólnotowego, red. C. Mik, Toruń 2007, s. 149-157. 
wym [europejskim - przypis M.M.] i odpowiada utrwalonemu orzecznictwu europejskiemu. Interpretacja przyjazna dla prawa europejskiego przy ocenie art. 20 $i$ art. 22 Konstytucji RP jako wzorców kontroli konstytucyjności powinna być jak najblizsza acquis communautaire ${ }^{37}$. Ma ona jednak swoje granice, ponieważ nie może doprowadzić do rezultatów sprzecznych z wyraźnym brzmieniem norm konstytucyjnych, której nie można eliminować przy zastosowaniu wykładni respektującej względną autonomię prawa europejskiego i prawa krajowego. Sytuacji takiej wykluczyć nie można, ale może ona - z uwagi na wspomnianą tożsamość aksjologiczną, wspólność założeń i wartości - pojawić się wyjątkowo ${ }^{38}$.

\section{Unijne podstawy i granice kompetencji prawodawczej państwa członkowskiego objęcia przedsiębiorcy w prawie krajowym minimalnym standardem ochrony odbiorcy w gospodarstwie domowym i konsumenta}

Prezentowana kompetencja prawodawcza państwa członkowskiego wymaga uchwycenia celu regulacji, który określony został w najważniejszych motywach zakreślających granicę prawidłowej wykładni dyrektywy 2009/72/WE oraz dyrektywy 2009/73/WE. W motywie 42 dyrektywy 2009/72/WE prawodawca unijny stanowi, że: [c]ały wspólnotowy przemysł $i$ handel, łącznie z małymi i średnimi przedsiębiorstwami, a także wszyscy obywatele Unii korzystajacy z gospodarczych przywilejów rynku wewnętrznego powinni także móc korzystać z wysokiego poziomu ochrony konsumentów, a w szczególności odbiorcy będący gospodarstwami domowymi, a także, jeżeli państwa członkowskie uznaja to za stosowne, małe przedsiębiorstwa powinny również móc korzystać z gwarancji usługi publicznej, szczególnie $w$ odniesieniu do bezpieczeństwa dostaw i uzasadnionych taryf, ze względu na uczciwość, konkurencyjność $i$, pośrednio, $w$ celu stworzenia nowych miejsc pracy. W zaprezentowanym ujęciu gwarancja usługi publicznej polega na zapewnieniu dostępności i jakości energii oraz przystępności cenowej. Nie wyczerpuje to możliwego katalogu działań zmierzających do rozciągnięcia postanowień z zakresu prawa cywilnego kształtujących ochronę konsumenta przed postanowieniami umownymi korzystnymi tylko dla dostawców, na małych przedsiębiorców (w warunkach polskich - niewątpliwie mikroprzedsiębiorców), czyli unormowań zapewniających wysoki poziom „ochrony odbiorców”. W mo-

37 Podobnie w uzasadnieniu wyroku z 21 kwietnia 2004 r., sygn. akt K 33/03, w którym Trybunał stwierdził, że: z chwila przystapienia do Unii Europejskiej Polska ma obowiązek stosowania się do zasad interpretacji wynikajacych $z$ dorobku wspólnotowego (acquis communautaire). Dotyczy to także metod wykładni stosowanych w orzecznictwie Trybunału Konstytucyjnego (...), w której istnieje konieczność interpretacji granic pojęcia wolności gospodarczej (art. 22 Konstytucji RP).

38 Zob. wyrok TK z 11 maja 2005 r., sygn. akt K 18/04. 
tywie 45 dyrektywy 2009/72/WE, stanowi się z kolei, że: [p]aństwa członkowskie powinny zapewniać użytkownikom będącym gospodarstwami domowymi, a także, jeżeli państwa członkowskie uznają to za właściwe - małym przedsiębiorstwom prawo do dostaw energii elektrycznej o określonej jakości o wyraźnie porównywalnych, przejrzystych $i$ uzasadnionych cenach. (...) W przypadku gdy ustuga powszechna dostępna jest również dla małych przedsiębiorstw, środki zapewniajace taka usługe powszechna moga różnić się od siebie w zależności od tego, czy dotycza odbiorców będących gospodarstwami domowymi, czy małych przedsiębiorstw. Odpowiednikami powyższych motywów w dyrektywie 2009/73/WE są motywy 43, 25 i $26^{39}$.

Zgodnie z art. 3 ust. 3 dyrektywy 2009/72/WE: [p]aństwa członkowskie zapewniaja wszystkim odbiorcom będacym gospodarstwami domowymi, a także, jeżeli państwa członkowskie uznaja to za stosowne, małym przedsiębiorstwom (mianowicie przedsiębiorstwom zatrudniającym mniej niż 50 osób i mającym obrót roczny lub sumę bilansowa nieprzekraczajaca $10 \mathrm{mln}$ EUR) możliwość korzystania $z$ ustugi powszechnej, to znaczy prawo do dostaw energii elektrycznej o określonej jakości, na ich terytorium, po uzasadnionych, łatwo i wyraźnie porównywalnych, przejrzystych i niedyskryminujacych cenach. Aby zapewnić świadczenie usługi powszechnej, państwa członkowskie moga wyznaczyć dostawcę z urzędu. Państwa członkowskie nakładaja na spółki dystrybucyjne obowiązek przyłączania odbiorców do ich sieci na warunkach $i$ według taryf ustalonych zgodnie z procedura ustanowionq $w$ art. 37 ust. 6. (...). Odpowiednikiem powyższego przepisu jest w dyrektywie 2009/73/WE przepis art. 3 ust. 3, który (odmiennie jak w dyrektywie elektroenergetycznej) przewiduje możliwości zapewnienia odpowiednich środków ochrony każdemu odbiorcy końcowemu.

Określone w przytoczonych motywach kryteria wykładni przepisów oraz wprost przepisy dyrektywy 2009/72/WE i dyrektywy 2009/73/WE w sposób jasny formułują możliwość potraktowania mikroprzedsiębiorców na równi z odbiorcą w gospodarstwie domowym w sferze poszczególnych uprawnień wynikających z prawa do usługi powszechnej. Kluczem do prawidłowej transpozycji regulacji unijnych do ustawodawstwa krajowego jest ustalenie właściwej - w prawie polskim - relacji zachodzącej między unijnym pojęciem małego przedsiębiorcy a przedsiębiorcą krajowym, w celu objęcia go standardem ochrony odbiorcy w gospodarstwie domowym (i ochrony konsumenta) i nieprzekroczenia (nienaruszenia) granic kompetencji prawodawczej. W tym względzie rozważyć można, po pierwsze, związanie miejsca działalności gospodarczej z miejscem prowadzenia gospodarstwa domowego, a po drugie - uzasadnione założenie granicy określonego wolumenu zużycia energii lub paliwa gazowego dla celów tej działalności. Zaprezentowane podejście nie przesądza negatywnie o dalej idącej możliwości rozszerzenia ochrony przedsiębiorców, lecz wychodzi naprzeciw

39 Zob. też art. 47 ust. 6 tiret czwarte oraz art. 52 ust. 6 tiret czwarte dyrektywy 2009/73/WE. 
normatywnemu (w ujęciu traktatowym i przepisów krajowych) obowiązkowi wsparcia mikroprzedsiębiorców.

Obydwie dyrektywy, 2009/72/WE i 2009/73/WE, zastrzegają, że przyjęte definicje użyte są wyłącznie na użytek każdej z dyrektyw (art. 2 in principio) dla pełnego zrozumienia ich treści i wytyczenia minimalnego standardu ochrony odbiorcy energii lub paliwa gazowego. Dyrektywy te wyraźnie przyznają kompetencje państwom członkowskim, poszerzając sferę możności działania m.in. Polski, aby rozszerzyć zakres ochrony właściwy odbiorcom w gospodarstwie domowym, określanych $\mathrm{w}$ dyrektywach także mianem konsumentów ${ }^{40}$. Nie ma przeszkód natury prawnej, aby kierując się zasadą prounijnej wykładni prawa krajowego oraz względami wykładni funkcjonalnej, w celu rozciągnięcia ochrony unijnego odbiorcy w gospodarstwie domowym (i konsumenta) na krajowego mikroprzedsiębiorcę uwarunkować jego ochronę od spełnienia jednocześnie cech odbiorcy w gospodarstwie domowym. W tym ujęciu nie ma naruszenia dyrektyw ani uprzywilejowania przedsiębiorców niezgodnie z ich unormowaniami, lecz przeciwnie - w wykonaniu dyrektyw następuje przyznanie określonej sfery ochrony, pod ściśle określonymi warunkami i w wąskim zakresie przedsiębiorców - tylko tych prowadzących jednocześnie gospodarstwo domowe, delimitując rzeczywistą ochronę do mikroprzedsiębiorców. Taki przedsiębiorca działa w warunkach domowych, w których główne zużycie energii lub paliwa gazowego przeznaczone jest do zaspokajania potrzeb socjalno-bytowych, a który ubocznie w swoim gospodarstwie domowym prowadzi działalność gospodarczą, w określonych projektowaną ustawą granicach - czyli de facto w niewielkim rozmiarze. Projektowana ustawa nie powinna dokonywać związania definicji proponowanej w ustawie - Prawo energetyczne z (zapożyczonym) pojęciem mikroprzedsiębiorcy zdefiniowanym i odrębnie funkcjonującym w innych unormowaniach sfery publicznego prawa gospodarczego, lecz polegać na pojęciach (definicjach) trwale zakotwiczonych i funkcjonujących już w ustawie - Prawo energetyczne. Trafność podjętego zabiegu legislacyjnego zapewni osiągnięcie założonego celu ustawy, spójność pojęciową w obrębie jednej regulacji, pożądaną zwięzłość tekstu prawnego i stabilność regulacji.

W prawidłowej implementacji przepisów zasadnicze znaczenie należy nadać rozeznaniu, w jaki sposób przyrównać definicję odbiorcy w gospodarstwie domowym dla określonych w dyrektywie (elektroenergetycznej) wartości (granicznych) kwalifikujących przedsiębiorcę do przyznania mu ochrony właściwej odbiorcy w gospodarstwie domowym i ochrony konsumenta. Wolumen zużycia energii elektrycznej w gospodarstwie domowym w Polsce ${ }^{41}$ wyklucza możliwość

40 Zob. art. 3 ust. 3 i motywy 20, 26, 42, 45 dyrektywy 2009/72/WE oraz art. 3 ust. 3 i motywy 25, 26 i 43 dyrektywy 2009/73/WE.

41 W Polsce większość gospodarstw domowych zużywa rocznie między 2001 a 3000 $\mathrm{kWh}$, przy czym przeciętne roczne zużycie energii elektrycznej w gospodarstwie do- 
osiągnięcia stanu zatrudnienia u przedsiębiorcy - przypomnieć należy, że w warunkach domowych - 50 lub większej liczby pracowników i jednocześnie osiągnięcia przez tego przedsiębiorcę obrotu rocznego lub sumy bilansowej $10 \mathrm{mln}$

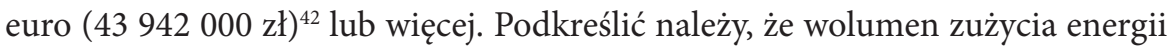
elektrycznej dla prowadzenia przydomowej działalności gospodarczej (z czym ściśle wiąże się odpowiednio niski wolumen energii cieplnej lub paliwa gazowego do ogrzania pomieszczenia przeznaczonego na tę działalność, na ogół wyodrębnionego od pozostałej części domu czy lokalu mieszkalnego) oscyluje w granicach 500 kWh zużycia energii elektrycznej rocznie. Dla porównania skali działalności - mały sklep prowadzony przez mikroprzedsiębiorcę na terenie szkoły lub dworca autobusowego czy typowy wolnostojący kiosk z prasą codzienną i artykułami wielobranżowymi - czyli miejsca wyraźnie odrębne od domu czy lokalu mieszkalnego - zużywają rocznie od $450 \mathrm{kWh}$ do $1037 \mathrm{kWh}$ energii elektrycznej. Wielkość miasta, w którym prowadzona jest działalność, nie jest istotną cechą kwalifikacyjną ${ }^{43}$. Stąd przekroczenie przez mikroprzedsiębiorcę (w warunkach domowych) poziomów (zatrudnienia i jednocześnie rocznego obrotu lub sumy bilansowej) określonych w art. 3 ust. 3 dyrektywy 2009/72/WE jest nierealne. $\mathrm{W}$ tożsamych uwarunkowaniach prawa unijnego niemiecki prawodawca uznał, że poziomy (wartości) określone w art. 3 ust. 3 dyrektywy 2009/72/WE są nie do przekroczenia w sytuacji zużycia przez przedsiębiorcę w warunkach domowych energii do $10000 \mathrm{kWh}$ rocznie ${ }^{44}$. Stąd w niemieckiej ustawie o prawie energetycznym (w $\$ 3$ pkt. 22 Energiewirtschaftsgesetz) odbiorcą w gospodarstwie domowym jest taki odbiorca końcowy, który zużywa energię (elektryczną, paliwo gazowe) głównie dla własnych potrzeb domowych, lub którego roczne zużycie nie przekracza $10000 \mathrm{kWh}$ dla potrzeb własnej działalności gospodarczej, rolniczej lub zawodowej. Prezentowana koncepcja rozwiązania prawnego znajduje zatem swój odpowiednik w prawodawstwie innego państwa członkowskiego UE oraz zawiera się w wyniku wykładni prawa unijnego.

mowym to zaledwie $2173 \mathrm{kWh}$, mniejsze zużycie jest w miastach - $1976 \mathrm{kWh}$, a większe na wsi - $2506 \mathrm{kWh}$, na podstawie danych GUS, www.stat.gov.pl [dostęp 11 lipca 2018 r.].

42 Według tabeli NBP kursów średnich walut obcych z 10 lipca 2018 r. 1 euro = 4,3356 zł, www.nbp.pl [dostęp 11 lipca 2018 r.].

43 Dane rynkowe dostawców i na podstawie analiz własnych autora.

44 Zob. $\$ 3$ pkt 22 Gesetz über die Elektrizitäts- und Gasversorgung (Energiewirtschaftsgesetz - EnWG) z 7 lipca 2005 r. (BGBl. I S. 1970, 3621, ostatnia zmiana z 20 lipca 2017 r., BGBl. I S. 2808). W odniesieniu do zagadnienia energii elektrycznej, to przeciętne 4-osobowe gospodarstwo domowe w Niemczech zużywa rocznie 2000-2300 kWh, wliczając ogrzewanie elektryczne, a średnia zużycia dla wszystkich gospodarstw domowych wynosi $4000 \mathrm{kWh}$ rocznie (na podstawie danych Bundesnetzagentur Federalnej Agencji ds. Sieci w Niemczech). 


\section{Traktatowe obowiązki państwa członkowskiego zapewnienia krajowym przedsiębiorcom unijnej swobody przedsiębiorczości i efektywnego korzystania ze swobód jednolitego unijnego rynku w wymiarze transgranicznym a obowiązki wynikające z prawa krajowego}

Można postawić tezę, że nieskorzystanie z kompetencji rozszerzenia na mikroprzedsiębiorców standardu ochrony odbiorcy w gospodarstwie domowym i konsumenta na mikroprzedsiębiorców utrzymuje w państwie członkowskim stan prawny upośledzający sytuację rodzimych mikroprzedsiębiorców (swoistą dyskryminację odwrotną). Mimo że nie jest to niezgodne z prawem unijnym, to jednak wykazuje niedostatek krajowego porządku prawnego dla osiągnięcia, po pierwsze, wynikającej z art. 49 TFUE gwarancji jednostkom (przedsiębiorcom) swobody przedsiębiorczości, a po drugie, wynikającej z art. 56 TFUE swobody świadczenia usług - w obydwu przypadkach w wymiarze transgranicznym. De iure oznacza to honorowanie przez polskiego prawodawcę korzystniejszej sytuacji prawnej mikroprzedsiębiorców np. niemieckich, świadczących usługi lub podejmujących wymianę towarową (transgraniczną) z podmiotami na rynku polskim, względem polskich mikroprzedsiębiorców. W tym układzie relacji polski mikroprzedsiębiorca nie jest objęty korzystniejszą dla niego ochroną (jak odbiorca w gospodarstwie domowym, konsument) w stosunkach handlowych wobec dostawców (krajowych lub zagranicznych), podczas gdy przykładowo w Niemczech przedsiębiorca w określonych granicach zużycia energii lub paliwa gazowego - jednoznacznie z takiej ochrony korzysta. Odmienność sytuacji prawnej odbiorców może mieć wpływ na koszty działalności gospodarczej i znaczenie dla transgranicznych warunków konkurencji.

Na podstawie art. 173 ust. 1 tiret pierwsze TFUE na państwach członkowskich spoczywa traktatowa powinność wspierania środowiska (czyli otoczenia - prawnego i gospodarczego) sprzyjającego inicjatywom i rozwojowi przedsiębiorstw w całej Unii, a zwłaszcza małych i średnich przedsiębiorstw. Spoczywa na nich również traktatowy obowiązek uczestnictwa w zbliżaniu ustawodawstw państw członkowskich, które ma na celu ustanowienie i funkcjonowanie rynku wewnętrznego (art. 114 i n. TFUE). Stąd sytuacja prawna polskiego przedsiębiorcy (tj. z siedzibą w Polsce) nie powinna być gorsza względem konkurenta $\mathrm{z}$ innego państwa członkowskiego, ponieważ narusza to unormowania traktatowe.

Proponowane rozwiązanie prawne wypełnia treścią normę programową (deklarację) prawodawcy polskiego i cele wspierania rodzinnych przedsiębiorców, zawarte w preambule ustawy z 6 marca 2018 r. - Prawo przedsiębiorców oraz $\mathrm{w}$ ujęciu pozytywnym - realizuje warunki i preferowany kierunek zmiany aktów normatywnych z zakresu prawa gospodarczego, w szczególności w kierunku przychylnym mikroprzedsiębiorcom (art. 66 i n. ustawy - Prawo przedsiębiorców). Trzeba też wspomnieć, że w poprzednio obowiązującej ustawie z 2 lipca 
2004 r. o swobodzie działalności gospodarczej, w jej art. 8 ust. 1, stanowiono, że: [o] rgany administracji publicznej wspieraja rozwój przedsiębiorczości, tworząc korzystne warunki do podejmowania $i$ wykonywania działalności gospodarczej, w szczególności wspieraja mikroprzedsiębiorców oraz małych i średnich przedsiębiorców $w^{45}$. Proponowana zmiana ustawy stwarza korzystniejsze warunki dla podjęcia i prowadzenia działalności gospodarczej w Polsce, spełnia cele społeczno-gospodarcze obydwu ustaw gospodarczych, poprawiając otoczenie prawne przedsiębiorców - i realnie poszerza sferę swobody działalności gospodarczej, na korzyść mikroprzedsiębiorców.

\section{Uwagi końcowe}

Z prawa unijnego wynika powinność państw członkowskich zapewnienia wysokiego poziomu ochrony konsumentów, w szczególności będących gospodarstwami domowymi, a także, jeżeli państwa członkowskie uznają to za stosowne, małych przedsiębiorstw, które powinny również móc korzystać z gwarancji usługi publicznej, szczególnie w odniesieniu do bezpieczeństwa dostaw i uzasadnionych taryf, ze względu na uczciwość, konkurencyjność i - pośrednio - w celu stworzenia nowych miejsc pracy, jak też prawo wyboru sprzedawcy. Odbiorcy ci powinni mieć dostęp do możliwości wyboru, sprawiedliwego traktowania, prawa do reprezentacji i mechanizmów rozstrzygania sporów.

Obecny krajowy stan prawny w poddanym analizie zakresie pogarsza swobodę przedsiębiorczości rodzimym przedsiębiorcom - zasadniczo w sferze praw i obowiązków umownych wobec przedsiębiorstw energetycznych - w wymiarze transgranicznym, wbrew art. 49, art. 56 i art. 173 TFUE. Prawo polskie normatywnie pogarsza warunki konkurencji rodzimych mikroprzedsiębiorców, niestety z korzyścią dla tożsamych przedsiębiorców z innych państw członkowskich. Źródłem kompetencji państwa członkowskiego wyeliminowania stanu zakłócenia konkurencji - przez zapewnienie w najwyższym stopniu krajowym przedsiębiorcom unijnej swobody przedsiębiorczości i efektywnego korzystania ze swobód jednolitego unijnego rynku w wymiarze transgranicznym są unormowania dyrektywy 2009/72/WE (elektroenergetycznej) i dyrektywy 2009/73/WE (gazowej). W wyniku analizy prawnej przeprowadzonej w niniejszym opracowaniu poddano pod rozwagę argumenty na rzecz określonego kształtu krajowej regulacji ustawodawczej, która wypełniłaby treścią krajowe unormowania statuujące obowiązek państwa wsparcia rozwoju przedsiębiorczości, w szczególności mikroprzedsiębiorców, poprawiając otoczenie prawne i poszerzając sferę swobody działalności gospodarczej tychże.

45 C. Kosikowski, Ustawa o swobodzie działalności gospodarczej. Komentarz, Warszawa 2013, s. 91. 
Naruszenie reguł konkurencji między mikroprzedsiębiorcami z przyznanym statusem odbiorcy w gospodarstwie domowym a innym przedsiębiorcą nie ma miejsca. Po pierwsze, z powodu przyznania w dyrektywie 2009/72/WE i dyrektywie 2009/73/WE kompetencji państwom członkowskim do rozszerzenia minimalnego standardu ochrony odbiorcy w gospodarstwie domowym i konsumenta na określoną grupę przedsiębiorców, a tym samym - normatywnego wyłączenia $\mathrm{w}$ tym zakresie reguł konkurencji. Po drugie, zaprezentowane w opracowaniu cechy kwalifikacyjne tej grupy przedsiębiorców, w tym niewątpliwie mikroprzedsiębiorców, z założenia eliminują z możliwości podwyższenia ochrony przedsiębiorców co najmniej o średnim stopniu oddziaływania rynkowego, co niweluje ryzyko rzeczywistego zakłócenia konkurencji. Niski poziom preferencji, na który składa się korzyść finansowa wynikająca z zakwalifikowania mikroprzedsiębiorcy (oczywiście, w określonym zakresie) do grupy taryfowej właściwej odbiorcy $\mathrm{w}$ gospodarstwie domowym, w realiach przyjętej niskiej intensywności działalności gospodarczej w warunkach domowych, nie spowoduje polepszenia sytuacji finansowej względem innych przedsiębiorców. Postulowane rozwiązanie prawne nie zakłóca konkurencji w warunkach krajowych - nie stanowi zagrożenia dla innych grup przedsiębiorcó $w^{46}$ ani też nie powoduje naruszenia podstawowych zasad traktatowych (tzw. progu odczuwalności).

Zbieżność terminologiczna pojęć odbiorcy $\mathrm{w}$ gospodarstwie domowym (w prawie energetycznym) i konsumenta (w Kodeksie cywilnym i innych ustawach normujących ochronę konsumenta) oraz niska intensywność działalności mikroprzedsiębiorcy w warunkach domowych przemawiają za kompleksowym rozciągnięciem przejawów ochrony prawnej odbiorcy-konsumenta na mikroprzedsiębiorców.

\section{Bibliografia}

Adamczak-Retecka M., Efektywność jako zasada prawa wspólnotowego [w:] Zasady ogólne prawa wspólnotowego, red. C. Mik, Toruń 2007.

Ahlt M., Prawo europejskie, Warszawa 1998.

Bednarek M., Wzorce umów [w:] System prawa prywatnego, t. 5, Prawo zobowiązań część ogólna, red. A. Olejniczak, Warszawa 2006.

Biernat S., Zasada efektywności prawa wspólnotowego w orzecznictwie Europejskiego Trybunału Sprawiedliwości [w:] Studia z prawa Unii Europejskiej, red. S. Biernat, Kraków 2000.

Długosz T., Ochrona konsumenta w sektorze energetycznym - zagadnienia wybrane [w:] Ochrona konsumentów i jej współczesne wyzwania, red. M. Ganczar, E. Sługocka-Krupa, Lublin 2014.

46 Por. ibidem, s. 576. 
Inny słownik języka polskiego, red. M. Bańko, Warszawa 2000.

Kalisz A., Wykładnia i stosowanie prawa wspólnotowego, Warszawa 2007.

Kosikowski C., Ustawa o swobodzie działalności gospodarczej. Komentarz, Warszawa 2013.

Łętowska E., Europejskie prawo umów konsumenckich, Warszawa 2004.

Łętowska E., Ochrona niektórych praw konsumentów. Komentarz, Warszawa 2001.

Łętowska E., Prawo umów konsumenckich, Warszawa 2002.

Marszałek M., Prawo do energii, „Państwo i Prawo” 2017, z. 11.

Mikłaszewicz P., Komentarz do art. $22^{1}$ k.c. [w:] Kodeks cywilny. Komentarz, t. 1, red. K. Osajda, Warszawa 2017.

Naworski J.P., Przedsiębiorca versus konsument, „Studia Prawa Prywatnego” 2018, nr 1.

Nowy Leksykon PWN, red. A. Dyczkowski, Warszawa 1998.

Pazdan M., Komentarz do art. $22^{1}$ k.c. [w:] Kodeks cywilny. Komentarz, t. 1, red. K. Pietrzykowski, Warszawa 2015.

Radwański Z. [w:] System prawa prywatnego, t. 2, Prawo cywilne - część ogólna, red. Z. Radwański, Warszawa 2008.

Radwański Z., Teoria umów, Warszawa 1977.

Słownik 100 tysięcy potrzebnych słów, red. J. Bralczyk, Warszawa 2005.

Uniwersalny słownik języka polskiego, t. 1, A-G, red. S. Dubisz, Warszawa 2003.

Ustawa o prawach konsumenta, red. D. Karczewska, M. Namysłowska, T. Skoczny, Warszawa 2015.

Ustawa o prawach konsumenta. Komentarz, red. M. Namysłowska, D. Lubasz, Warszawa 2015.

Zelek E., Niedozwolone klauzule umowne $w$ umowach sprzedaży energii elektrycznej, „Energetyka” 2012, nr 5, www.cire.pl. 